\title{
Article
}

\section{The Nexus of Political Violence and Economic Deprivation: Pakistani Migrants Disrupt the Refugee / Migrant Dichotomy}

\author{
Bhimji, Fazila
}

Available at http://clok.uclan.ac.uk/21044/

Bhimji, Fazila ORCID: 0000-0002-7234-852X (2018) The Nexus of Political Violence and Economic Deprivation: Pakistani Migrants Disrupt the Refugee / Migrant Dichotomy. Journal of Immigrant \& Refugee Studies, 16 (4). pp. 470 487. ISSN 1556-2948

It is advisable to refer to the publisher's version if you intend to cite from the work. http://dx.doi.org/10.1080/15562948.2017.1417521

For more information about UCLan's research in this area go to http://www.uclan.ac.uk/researchgroups/ and search for <name of research Group>.

For information about Research generally at UCLan please go to http://www.uclan.ac.uk/research/

All outputs in CLoK are protected by Intellectual Property Rights law, including Copyright law. Copyright, IPR and Moral Rights for the works on this site are retained by the individual authors and/or other copyright owners. Terms and conditions for use of this material are defined in the policies page. 


\section{The Nexus of Political Violence and Economic Deprivation: Pakistani Migrants \\ Disrupt the Refugee/Migrant Dichotomy.}

\section{Introduction}

The study examines how Pakistani migrants in Germany understand Pakistan's political and economic situation. The essay demonstrates how their narratives of poverty, political violence and on-going corruption within Pakistan interweave. The study demonstrates that reasons for their mobility needs understanding in multi-tiered ways. The Pakistani migrants believe that political violence and acts of terrorism affects the poor directly, while the elite manage to shield themselves with private security or manage to leave the country with relative ease. More specifically, the study includes Pakistani migrants' perspectives on the interlocking of political and economic conditions at the level of the state, as well as at individual, regional and global levels. Immigrant officials, interviewers, asylum policy-makers fail to recognise the more complex experiences of asylum-seekers. The accounts offer a much more complex set of reasons for their decisions to emigrate from Pakistan. In doing so, the paper calls for inclusion of broader definitions within policies, which determine status of refugees in host states.

Given that nation-states are more likely to accept asylum-seekers who recount experiences of political violence, well-intended media have constructed migrants affected by a complex set of factors as refugees and as victims of political violence. On 20 August 2015, Al-Jazeera English, online editor Barry Malone in an article entitled 'Why Al Jazeera will not say Mediterranean 'migrants' explained its' decision as follows:

Many thanks to Caroline Blunt for her comments on the early drafts of this paper. Many thanks also to the anonymous reviewers for their useful comments and feedback. 
There is no "migrant" crisis in the Mediterranean. There are a very large number of refugees fleeing unimaginable misery and danger and a smaller number of people trying to escape the sort of poverty that drives some to desperation (Malone 2015)

Thus Al-Jazeera made a distinction between economic migrants and political refugees. The rhetorical choice of Al Jazeera was met with criticism in sociological scholarship. Christopher Kyriakides (2016) argued that Al Jazeera's decision to employ the word 'refugee' and to distance themselves from using the word 'migrant' was in effect in line with OECD countries' policy of constructing a hierarchy of deserving highly skilled migrants and the depiction of refugees as trusted noneconomic and non-threatening victims which in turn reproduced and reinforced racialized codes. This paper based on the narrated experiences of people from Pakistan in Germany, argues that it is important to include both political and socioeconomic rights in policy and legislation.

\section{Forced Migration and Voluntary Migration}

Forced migration is associated with political motives and voluntary migration with economic motives, but in actuality the reality is much more complex and economic and political reasons for migration often intertwine (e.g. Lindley 2009; Van Hear 2009; Richmond 1994; Koser 2011; Crawley \& Skleparis 2017). The identity of a refugee is fixed as defined by the 1951 Refugee Convention and a state's policies and politics dictate the types of refugees and immigrants that they are willing to grant asylum to in a country. Refugee law throughout the world has traditionally differentiated between refugees and economic migrants. The definition of a refugee in international law, Article $1 \mathrm{~A}(2)$ of the 1951 United Nations Convention, is understood as a definition of a 'political refugee' as opposed to an 'economic migrant.'(Ghosal and Crowley 1983). Thus, the UN Convention supports political 
rights and excludes socioeconomic rights. In this regard, there has been much discussion and debate with regard to the differences between economic migrants and political refugees in scholarship. Crawley and Skleparis (2017) note that these debates have led UNHCR and a multitude of other national, international and civil society organizations to privilege the rights and needs of a category of people who are known to be 'refugees' over economic migrants.

There has been a move to politicise the notion of economic migrants. Peter Nyers asserts that 'even when so-called economic migrants are motivated by fear fear of hunger, of poverty, of homelessness and so on - this fear is emptied of any political quality and is recast as 'despair.' (2006, p. 50). Forced migration and voluntary migration have been understood in nuanced ways. Legal scholar, Jenifer Klinck argues that in the refugee law context, the traditional refugee/migrant dichotomy is substantially founded upon the assumption that economic migration is voluntary and that economic migrants are not recognised as refugees because their decision to leave in order to seek a better life is set up in opposition to political refugees whose migration is involuntary or forced. She rejects the refugee/migrant dichotomy and argues that the categorical distinction between refugees and economic migrants is unhelpful/ inaccurate since severe socio-economic rights' deprivations often have a political nexus. Crawley and Skleparis (2017) challenge the categories 'migrant' and 'refugees' and demonstrate that 'the decisions made by these individuals to leave their countries of origin, and the process by which they arrived in Europe, were more complex than presented by politicians, policy-makers and the media' (p. 3). 
Sociologists have further discussed the reasons for the emergence of the stark divisions between migrants' experiences of political conflicts and their experiences of economic hardship in policy making. Studies have identified free market economics and demands of nation-states for high skilled migrants as explanations for the emergence of refugees and migrant categories. Zetter (2007) asserts that given the reluctance of these countries, until recently, to relax national immigration controls and open their labour markets, refugee status has remained the only systematic and relatively accessible entry route for large-scale, globalized migration. Legal scholars have argued that the distinction helps facilitates the rejection of asylum-seekers who seek refugee status on economic grounds. In other instances, the economic migrant is understood as the political refugee even though free market economics and globalism have led to the collapse of political and economic categories (Gonzalez 2000). Although there have been discussions which help explain the reasons for the emergence of the dichotomous categories, the bottom-up perspectives of refugeesmigrants regarding their country of origin's political and economic situation has received less attention. The focus within these discussions has remained on the global world order and destination countries rather than the migrant's country of origin. This essay demonstrates how Pakistani migrants residing in Germany, through their representations and understandings of their homeland at the state, regional, individual and global level blur the divisions between political violence, corruption and economic inequalities. In doing so, the study, through empirical data, contributes to the scholarly debates with respect to the complex realities of political and economic factors resulting in migration from conflict-ridden and economically struggling states.

The paper argues for the diffusion of categories such as 'refugees' and 'economic migrants' such that one category is not privileged over another in policies, 
media and legal discourse and experiences of economic hardships are understood in conjunction with political violence. Furthermore, the study demonstrates the ways in which the migrants had developed a sophisticated critical discourse denying the validity of this distinction while adopting quite far-reaching critique of contemporary Pakistan. The essay by doing a fine-grained analysis aims to capture the agency of Pakistani migrants in their decision to refuse to negotiate with the very difficult political and economic conditions within the country, to cross regimented EU borders and to strive to attain dignity elsewhere while the live with Duldung legal status (deportability) in Germany. Thus, agency in this specific context is understood as struggles and decisions undertaken by abject groups of people to resist structural mechanisms with the aim to improve their life chances. Strange et al (2017) assert the importance of a focus on struggles by individuals who are irregularised since it enables appreciation of the ways in which the marginalized make decisions, enact change and participate in claims-making. Thus, the very presence of unauthorized migration within a privileged and heavily policed EU can be interpreted as evidence of agency of those migrating and thus of the limitations of structural inequalities and institutionalized mechanisms of control (Squire 2017).

This study first provides an overview of Pakistani migration in Europe. Subsequently, the paper discusses Pakistani migrants' understanding of Pakistan as a poor country in comparison with western nation-states such as Germany vis-a vis the lack of visibility given to Pakistan's experience of recurring political violence in international media. I then examine the complex interweaving of economic concerns and political conflicts as related by Pakistani migrants in Germany along two themes. Firstly, I discuss their understanding of the entanglement of corruption with political violence and its' consequences on the poor. Secondly, I examine how they come to 
connect regional poverty and political violence. The Pakistani participants' everyday realities as well as their understanding of Pakistan's political and economic positioning convey that they refuse to categorize themselves as either 'refugees' or 'economic migrants', but rather believe that their particular socioeconomic and political context as well as the nation-state's economic and political situation makes them deserving of asylum in the host country, Germany.

\section{Methodology}

The study is based on 18 in-depth semi-structured interviews from July to September 2016 with refugees and migrants of Pakistani origin from differing regions. The informants appear in the text under fictitious names. In addition, I followed the political events within Pakistan closely through the online Pakistani English newspapers.

I focused on Pakistani migrants in particular because there are a significant number of Pakistanis in Germany (in the year 2015, there were 8,199 asylum-applicants from Pakistan in Germany) with the majority asylum cases rejected on the grounds that the German state did not recognise the asylum-seekers to be directly affected by political violence within the country. Throughout the essay, I refer to the participants as migrants rather than asylum-seekers or refugees. Migrants, understood in this way are people who move under different circumstances and for a variety of reasonsincluding refugees who are in fear of persecution (Carling 2017).

The focus of the interview questions aimed to get insight into the ways the participants understood the general economic and political conditions in Pakistan and their respective regions of origin. I did not ask for personal testimonies and their specific reasons for being in Germany since the study's aim was to comprehend the 
complexity of the general situation, which affects many of its' citizens -particularly the poor - which in turn result in migration. Furthermore, I aimed to achieve an understanding of the migrants' own understandings and interpretations of how political violence and economic deprivation in the global south could affect people. Twelve of the interviewees were from various towns in the province of Punjab, four of them were from Peshawar, and two of the migrants were from Quetta. They told me that they were from low to lower-middle income social backgrounds within Pakistan.

Since the majority of the immigrant population who reside in Germany from Pakistan, constitute men, I interviewed male migrants. Their ages ranged from 20 to 35 and their education level varied, but only three of the people I interviewed had completed formal schooling and had acquired some college education. All interviews were conducted in Urdu and translated into English. I employed snowballing technique for finding research subjects. Snowballing technique has been identified as a process which is based on the assumption that a 'bond' or 'link' exists between the initial sample and others in the same target population, allowing a series of referrals to be made within a circle of acquaintance (Berg, 1988). I conducted the interviews in cafes, refugee accommodation and a youth club, which, people frequented. Because several of the participants I was in contact with, lived a short distance from Berlin, I invited many of the interviewees for coffee in the city and conducted the interviews in Berlin as well as in towns such as Hennersdorf and Hellersdorf surrounding Berlin. Since I am of Pakistani origin, from the country's largest city, Karachi, and spoke Urdu fluently I easily developed connections with the people I interviewed. However, at the same time, I was conscious of differences in gender, class, educational, and citizenship background. However, these differences did not prove to be a barrier, 
since the people I interviewed easily engaged in conversations with me about the political and economic situation of Pakistan as well as their lives in Germany.

Finally, it must be noted that the interviews took place in Germany amongst migrants who had a certain perspective on Pakistan at the time I interviewed them. Pakistan's recent politics seemed to have improved, since the Supreme Court ousted Pakistan's current government on charges of corruption. The electricity crises have also improved in the major cities. However, the violence continues towards Sufis, Shias, and the Christian populations and their spaces of worship despite the paramilitary's strong presence throughout the country.

\section{Pakistani Migrants in Europe}

Pakistan is a third world country. According to the UNDP Human Development Report 2014, Pakistan ranked 147 out of 188 countries in the Human Development Index such that $45.6 \%$ of the population are multi-dimensionally poor. Life expectancy for females was recorded at 67.2 and for males at 65.3; education level was at 3.1 years of schooling for females and 6.2 for males. Gender inequality (GII) was at 121 out of 155 countries. Pakistan received a total of 18.4 billion USD remittances in the financial year 2014, the seventh largest amount of remittances any country received globally (Abdin and Erdal 2016).

Pakistan's economic and development situation is difficult in several respects. Pakistan continues to experience a 'protracted electricity crisis' such that load shedding necessitates the use of alternative sources of electricity generation, and due to high prices, maintenance charges, and the fuel cost of these sources, the monthly expenditure of the household tends to increase (Abdin \&Erdal 2016). The urban 
centre, Karachi can experience 12 hours of load shedding per day, whereas rural zones experience up to 20 hours of electricity cuts (Aman et al., 2013).

The majority of Pakistani immigrants reside in Saudi Arabia (60.96 percent), followed by the UAE (28.13 percent) and other Islamic countries ( 9.45 percent). Only $1.47 \%$ of Pakistani immigrants are in Europe and other non-Islamic countries in Asia (Hasan 2010). A significant majority of the Pakistani diaspora within Europe resides in the UK. (Karla 2000; Werbner 2002) However, Pakistani migrants also reside in Norway and Denmark (Bolognani and Erdal 2016; Rytter 2013). Migration from Pakistan to countries in Europe could be understood in terms of two distinct phases; at first the regular phase and the irregular at a later stage (Yousef 2013). Among receiving countries of this irregular phase is Greece, the case of which is particularly interesting, as it has evolved today into an irregular migration junction from Pakistan into the wider Europe.

Migration pattern in Pakistan is related to its' geography. Prior to independence from Britain, people from Mirpur in Kashmir worked in industrial labour in Bradford and Birmingham. In the 1950s and 1960s the numbers rose because sections of Mirpur and its surrounding areas were converted into a huge water reservoir on account of a mega irrigation project with the UK government being one of the international guarantors for the project. (Karla 2000). At that time, many people also migrated to Norway. In the 1970s and 1980s there was an increase of Pakistanis immigrants to the Nordic countries, which was followed by the gradual movement of the female population for family reunification reasons (Yousef 2010). i The first flows of irregular movement to EU countries appeared through various difficult routes such as Turkey, Serbia, and Greece in the 1990s. According to the IOM reports, the number of asylum seekers from Pakistan in the EU amounted to 
22,000 asylum applications in 2014 and 44,745 in 2015, with a low recognition rate of respectively less than $15 \%$ and $30 \%$. According to the Eurostat database, in the year 2015-2016, 52,745 people from Pakistan applied for asylum for the first time within the EU Member States.

In the year 2015, there were 8,199 asylum-applicants from Pakistan in Germany. Pakistan ranked amongst the top ten countries with asylum-claims in Germany. According to the Bundesamt für Migration und Flüchtlinge (BAMF) reports, in 2015, the success rate for asylum-applicants in Germany was $9.8 \%$ with more than $90 \%$ rejected. In 2016, January, it dropped even lower - with just $4.5 \%$ of asylum requests being granted within the EU. It is estimated that only one in ten asylum seekers from Pakistan receive protection status, but the rest manage to stay in Germany. However, only two people were repatriated to Pakistan in 2014 from Germany despite the rejection of 580 asylum applications from people from that country. The year before just three out of 533 returned. The common knowledge among migrants for such low statistics was that Pakistan was among the countries reluctant to take back its own citizens on account of economic factors. It was also commonly understood that Pakistan had become reliant on remittances, which families receive from young males living in Europe.

Hundreds of civilians in Pakistan have been killed in recent years, with the Taliban or its splinter groups claiming responsibility for many. There have been more than 500 people killed in various 'terrorist' attacks resulting from violent religious extremism since December 2014 (Boehler and Lai 2016). According to the Institute for Economics and Peace, the casualty rate declined, but Pakistan had the fourth highest number of terrorist attacks (1760) of any country. These forms of violence have continued to a significant degree into the current year. In 2017, February 88 
people were killed and injuring at least 343 people when a suicide bomber attacked a Sufi shrine in Sindh.

The following paragraphs explain how the refugees and migrants themselves actually understood the political violence and economic deprivation in Pakistan and in doing so subverted the categorical dichotomous definitions of economic migrants and political refugees.

\section{Reading the Media: Pakistan as a Poor and Politically Volatile Country}

This section shows that the participants understood Pakistan as an economically less developed state as well as a state, which experienced frequent occurrences of violence. The migrants understood Pakistan to be absent from international and local media coverage even in the face of on-going conflicts and violence because of its' weak economic position. For example, Bilawal offered the following viewpoint:

Because Pakistan is a poor country nobody gives attention when there is violence in the country. Now look at the Germans in light of the small incidents of the last week the Germans are paranoid. In the trains, people are giving us looks. So when a poor country such as Pakistan, which has witnessed much incidents of terrorism, how can it be considered safe? There is not much literacy in Pakistan. Poor people are then forced to resort to crime in Pakistan in order to support their families, what can they do? In such a country, if you go to the government hospital, the doctor will tell you to visit his private clinic and charge the common person exorbitant fees.

Bilawal makes a comparison with the media attention that was given to the occurrences of violence in the German State. He compares Germany to Pakistan arguing that the degree of violence and conflicts have been much greater in Pakistan but received disproportionately less attention. He believes that because Pakistan is a poor nation it was deemed less worthy of media attention. Thus, Bilawal highlights the notion of Pakistan as a poor state simultaneously affected by political violence. Subsequently, he provides experiences of the poor living in Pakistan. Thus in this way 
Bilawal recognises that both the political and economical situation of Pakistan remain unstable.

Faisal offers a similar viewpoint

Pakistan faces much extremism. There are training grounds to promote extremism. There have been bomb blasts and extremism going for several years but the western media does not give the same level of importance as it does when lives are lost in rich countries in Europe. Now in Germany, there were instances of terrorism in the last few days and the entire nation has been shaken up. Pakistan has been living with extremism for years. There were instances when there were bomb blasts in four cities at the same time, but there was not much attention paid. What can Pakistanis do when the security tells the Pakistanis in such cases to shut down businesses and stores and to go home because we cannot take care and be responsible for terrorism?

Thus, Faisal recognises that extremism, militancy and terrorism prevails in Pakistan.

He understands that in comparison to an economically rich state such as Germany, the situation has received less attention. Thus for the participants in Germany, Pakistan is understood to be both a poor as well as a politically violent country. The Pakistani migrants are of the viewpoint that if Pakistan had been an economically strong nation, then the international media would have given the recurring violence further visibility. The media's omission to depict the frequent occurrences of political violence in Pakistan is understood in economic terms. Thus, the Pakistani migrants in Germany understand Pakistan as an economically disenfranchised country and one that also experiences recurrent political violence.

\section{Interdependence of Corruption, Political Violence and Poverty}

While the above section illustrated how the Pakistani respondents understood the conditions in Pakistan in relation to countries with stronger economies, this section illustrates how the people understood the actual intersection of corruption, poverty and political violence. Doig and Roiley (1998) understand corruption to involve the undermining of public office for private gain, but they additionally link 
corruption to lawlessness, which include fraud and organised crime. The Pakistani migrants in Germany understood corruption in a similar way, but they also observed the connections between corruption and sustained militancy and political violence in Pakistan and the consequences the undesired situation had on the economically poor. The following accounts demonstrate these points of view.

Jamil: There are many forms of terrorism in Pakistan. But there is much corruption in the country as well. Corruption does not mean that someone is eating up money. Corruption also means that when one is not catching the person who is breaking the law and committing terrorist acts. This is also corruption. So corruption and terrorism are intertwined. Maulvis (religious leaders) and Islamists have created many problems in Pakistan. Extremism is on the rise. The government exploits religious people.

In the above excerpt, Jamil describes the heightened levels of corruption within

Pakistan. When it is understood that it becomes difficult to contain violence because of heightened levels of corruption, then people's fears of persecution and economic deprivation need to be understood along a nexus.

Similarly, Ahmad explained in the following account:

On top of everything, there are conflicts going on in Waziristan, Europe and American and Pakistan army are aligned together to fight the Talibs. There are no laws. The laws are being made. People can be killed, but they are out the next day. And they say Pakistan is a safe country. How can it be a safe country?

Wade (1985) has pointed out that corruption -whether incidental, systematic, or systemic -has often been found to have profoundly damaging political, social and economic effects, although its political consequences are variable. In the case of Pakistan, many believe that on-going corruption has led to an increase in militancy, extremism and violence. In this regard, while adopting a critical view of the country, Pakistani migrants understand the connections between corruption and increased violence. In this regard, they also understand themselves of deserving of asylum 
because of these complex factors and thus refuse to be characterised as either political -forced migrants or voluntary -economic migrants.

The following accounts demonstrate how individual economic situations come to intersect with political violence within Pakistan.

Mehmood: There is much terrorism in Pakistan. The police cannot help-again if one has money then the police help out but if one does not have enough money then the police do not help. There is no protection of life in Pakistan. There is no guarantee whether you could come to your house safely once you leave the house.

Junaid: There is much lawlessness and terrorism in Pakistan. Where there is no law, it is not possible to have a country. If you go to the police station, then you can pay the person. For the low-income person, Pakistan is not a safe country. If you have money, power, and influence, then it's a safe country. Politicians keep their money out of the country. People are only looking out for themselves. If there is an accident on the road, and if you are poor, then there is no one on the road to take care of you. If you go to the government hospital then there is nobody to take care of you.

Ali: Pakistan has been fighting terrorism for 20 years. Pakistan has suffered the greatest consequences because of terrorism. Thousands of civilians have died. There have been countless suicide attacks in Pakistan. There have been target killings all over Pakistan. There are many instances of 'Bhatta Khori'. These are all politicians using for their votes. So even the common person gets scared and votes for the politicians. The common person's voice is not heard. The common person simply dies on the 'charpai' (bed). The corrupt politicians are responsible for this situation A poor person in Pakistan has no rights. For example if someone murders someone, if he is rich, the person is free -but if it's a poor person then no one hears his voice. If he goes to the police station, then the police will write his report, if he has money. If he has no money, then the police will tell him to leave. This is corruption but the poor are affected by it.

The motives for the corruption in Pakistan might be very complex, but as Ali, Junaid and Mehmood point out that, the economically vulnerable individuals have little recourse since they cannot afford to pay the price of justice. Ali mentions the prevalent cases of 'Bhatta Khori' when politicians, allegedly at gunpoint, collect bribes from small businesses such as vegetable and fruit shops. Thus the Pakistani migrants understand that it's the economically poor individuals who are most affected since they often own small and informal businesses and find themselves in vulnerable 
states when unable to seek help from the police. They are left without much recourse and experience poverty and political violation simultaneously. Junaid explicitly mentions the stark differences between the poor and the rich. For the poor there is little recourse but for the rich, Pakistan is a 'safe' country. Thus, the economically disaffected believe that they are caught in a web of struggle against terrorist acts, target killings, police corruption, bribery, and corrupt politicians.

The above accounts demonstrate the extent to which the Pakistani migrants understood conflicts to be linked with corruption and the adverse effects it has on the economically disenfranchised. Their accounts of their quotidian realities show that militancy gives rise to corruption and conversely because of corruption, militancy cannot be curtailed.

The accounts of the Pakistani migrants show that they have to negotiate corruption and conflict simultaneously. As Adnan points out

There is much terrorism in Pakistan. Every single day there are conflicts and inflation is high. There is not much law and order. Because of corruption and bribery, people who have money, their voices are heard and those that don't have money they suffer. I finished matric (matriculation) but I did not see the point of attaining higher education. People who have higher education, they are selling tea. To get a good job you have to have 'sifarish' (influential people's advocacy). So I left Pakistan and came to Germany.

Thus Adnan's account demonstrates the rise of economic inequalities within Pakistan within a climate of political violence. In this context, political violence gives rise to inflation and further corruption. . The account demonstrates that it is not possible to demarcate between forced migration and voluntary migration since Adnan's decision to build a future for outside his home country were based on a set of complex factors which included political violence as well as economic hardships. 
Bartram (2016) points out that the concept of 'forced migration' needs to be understood more broadly such that even when options may become available in particular situations, individuals may regard these alternatives as unacceptable because they may impinge on human dignity. In this regard, Adnan had the options to remain in Pakistan and contend with the violence but had he continued with his education, he would have earned minimum wages. Thus, both political violence and the lack of economic prosperity played a role in his decision to migrate to Germany. Therefore, it needs to be understood that unstable conditions in Pakistan brought about inflation from which only the rich could find recourse.

The migrants in Germany understand the involvement of state actors as well as external forces playing a role in conflicts but because of corruption, conflicts continue to prevail:

Mansoor: There are constant political conflicts in Karachi between the various political parties such as MQM, Balochis, Afghans, and Pathans. India is also behind terrorism in Pakistan. But the generals on the top are eating away -even when they have a headache, they go to England for their treatment. They just want to escape the hot summer months of Pakistan.

Thus, there is much criticism of the elite class, the politicians, and the various institutions by the economically less privileged in Pakistan. In this respect, the participants display much insight into the nuances of political conflicts and level of corruption within Karachi. The use of humour becomes commonplace to recognize the ways in which the elite class and politicians waste economic resources which ultimately affects people from lower socio-economic backgrounds and does not help to curtail political violence. Thus, the participants' decisions to leave Pakistan for Germany should be best understood as acts which arise from the complex intersection of political and economic situation in Pakistan with the poor having less options than the elite. 
On the one hand, the Pakistani participants in Germany emphasise the level of conflicts in Pakistan, which include extremism, militancy, and everyday forms of political violence, but in the same instance they point out that that it is the economically vulnerable who bear the brunt of persecution while the rich find ways to protect themselves against violence. Their narratives demonstrate that corruption, rising inflation, economic inequalities and political violence are interdependent factors, which cannot be explained in isolation of each other. Thus, migrants needs to be understood in broader terms in policy, media and legislation and their range of experiences need to be included.

Van Hear (2006a) contends, that 'the capacity for a would-be migrant to navigate the international migration order will be largely shaped by his or her endowments of economic and social capital, or the amount of economic, social and other capital a would-be migrant can call upon'. However, in this context it is the poor who have limited resources are forced to contend with corruption and violence and thus decide upon migration. Consequently, they incur much debt for their long and arduous journey to Europe. Yet at the same time, their migratory process shows their agency given that they decided not to become victims of such hardships and undertake arduous journeys to Europe.

\section{Connections between Regional Violence and Economic Deprivation}

While the above discussion explained how corruption, individual and state poverty and corruption came together, this section sets to point out the intersections between regional poverty and political conflicts and consequently the importance of

diffusing the categories 'refugees' and 'economic migrants' in policy and discourse. People from certain regions cannot be understood to solely experience political or 
economic violence in isolation. Very often because of media attention, certain cities and towns come to be associated with heavy political violence as was the case of Aleppo in Syria. The economic consequences and the experience of the poor in comparison to the rich in those regions are often omitted in media discourse. Conversely, other regions within a nation-state are understood as violence free, but the lack of economic resources within those regions does not become a focal point.

The people in Pakistan who had asylum-claims in Germany were from differing regions in Pakistan. Some of the migrants were from towns where there was less violence but more pronounced economic inequalities. Others were from towns such as Peshawar and Swat, where the violence was visibly more pronounced. These towns and tribal areas had also received relatively more media attention since they bordered Afghanistan and were understood to experience instances of attacks from various militant groups. Some participants spoke of the continued violence in urban cities such as Karachi. Several of the Pakistani men I spoke with recounted the dire situation in these regions. However, at the same time, the men spoke of their experiences of poverty and unemployment.

Arshad and Mehmood speak of violence, corruption and poverty in Swat and Peshawar:

Arshad: In Swat, there is a heavy army presence everywhere. There are check-posts everywhere. One cannot even go to the hospital on time even if one is wounded. If one is with the Pakistan army, then the Taliban comes and does target killing. So people disguise themselves. Those people who are even in peace committees also become the target of Taliban killings. NGO projects cannot run. People who are involved in NGO projects are shot down. I had an uncle who went to the store in a full bazar in Swat during the day who was shot down. Where was the army then? Who was behind it?

Mehmood: There are problems in the girls' schools. They are detonated. Talibans go inside that and children are shot, teachers are shot. If this is right, then what can be wrong? I know so many people who are killed. There are many widows who remain unsupported. The government does not support them. There is no work in Swat. People work as farmers on peas, potatoes. They sell at the same prices as 10 years 
ago. But the price of flour and sugar has gone up 5 and 10 times. So, this is corruption. The bill for electricity has gone up. The poor cannot afford electricity. There is much water in Swat but no electricity. It is all corruption.

Thus, Arshad and Mehmood describe political violence, corruption and economic instability within Swat in Pakistan. There had been some media attention on Swat following activist Malala Yousefzai's case of injury by the Talibans in Swat. Popular and academic sources provide one-dimensional political explanations as exceptional phenomena for mobility from the Swat region (Walsh and Haq 2009). However, the participants offer a nuanced viewpoint and demonstrate the ways in which conflict has an impact on the everyday lives of the people, which affect their daily livelihoods. Thus, the accounts demonstrate that Swat is not only affected by political violence but also become subsumed in poverty. In this regard, migration from Swat need to be understood as the combined effects of economic and political instability rather than simply as a consequence of political precarity.

Anwar explains the intersections of terrorism, corruption and economic disaffection in Peshawar:

In Peshawar schools were attacked. There is terrorism, corruption and poverty everywhere. Life is in danger because of India and America. [The] Indian army is in conflict with [the] Pakistan army. Army public schools have been attacked and 600 children were killed. Because Pakistan is fighting the Talibans in Waziristan, the Talibans in response attacked the schools where the children of the army were studying. The University of Peshawar was attacked. But for the rich, it is still okay, because the rich have security guards. It's the poor who go to open bazars and their lives are threatened. The poor cannot afford such security.

For Anwar, lives in Pakistan become precarious because of the interference of external countries such as India and the United States and he believes that as a consequence the Talibans respond in particular ways. However, more significantly, the dire political situation continues to affect the lives of economically disenfranchised on a daily level. He believes that it is the poor who become more 
vulnerable than the rich who have the means to self-protect themselves. What is significant in Anwar's account, as was in other descriptions, is that even in violence inflected regions within Pakistan, the sufferings and their reasons for migration of the residents of Peshawar and Swat needs to be understood beyond that of an exceptional phenomena, since disruptions of economic activity, corruption interplay with conflict as well in this part of Pakistan. Thus, the changing landscape of violence can translate in significant ways into the every- day lives of residents (cf. Lindley 2009). The ways in which such shifting geographies can affect people often remains invisible and the focus remains on macro-political structures. The lives of the participants are affected in intricate ways and their reasons for migration cannot be explained by a divided classificatory system of forced or voluntary migration in policy and media. While it may hold true that children in army school could also include children of the affluent, but generally speaking in a country with much inequality it is the poor who would have potentially less recourse to protect themselves against potential forms violence related to extremism as was depicted in the above account.

Malik believed that terrorism and target killings in Peshawar further escalated poverty in the state.

There is much terrorism in the tribal areas in Pakistan. Peshawar is surrounded by tribal areas. There is much terrorism in areas, which border Afghanistan. There is less in Punjab. In Karachi, there are many instances of terrorism and target killings There was always good work in Karachi. People used to go to Karachi to find work from small villages. Karachi was known as the poor person's mother because one could find work in Karachi. The poor always went to Karachi. The rich who had assets would come to Europe, but now because of the difficult situation, people started to come to Europe since 2000. Prior to this only people from villages and towns were coming to Karachi -but then people from cities also started to come to Europe.

Malik speaks of the violence in Peshawar, but at the same time, he also notes how Pakistan's biggest urban city, Karachi, suffers from political violence. In this 
connection, he states that the poor, who were accustomed to migrating from rural areas to the core urban centre, Karachi, with the purpose of finding employment, could no longer do so because of increased violence in the city. Thus, for migrants such as Malik seeking increased income in core cities such as Karachi, the main driver for their movement from rural villages to urban centres has been largely unequal economic conditions. However, given the increased violence and corruption (and general strike days) in cities such as Karachi, people are reluctant to internally migrate but rather decide immigrate to Europe.

While many of the participants described the prevalence of conflicts in their cities and towns, Anjum spoke of his town Sialkot to be free from violence, but suffering from poverty.

There is no guarantee whether you could come to your house safely once you leave the house. Sialkot is very normal. Gujranwalla is very normal. In Karachi there is much terrorism but not in Sialkot. But load-shedding is all over Pakistan. But people who have their own businesses could not run the businesses because of load shedding. Load-shedding has increased. In my village there is 20 hours of loadshedding. In some instances, on a continuous basis -sometimes for two days in a row, there is load-shedding. This is why $80 \%$ of the people who are here from Pakistan are the poor. But the poor cannot go to Karachi anymore because there is so much violence in the city.

Thus for Anjum, Sialkot, was free from violence in comparison with other parts of the country. He pointed out that economic deprivation, electrical shortages (loadshedding) prevailed all over the country. Several studies have documented that the electricity crisis in Pakistan has since 2007 had severe detrimental implications socioeconomically on the country's development (Ellahia, 2011; Jamil, 2013; Jamil \& Ahmad, 2010; Shabbaz \& Lean, 2012; Abdin and Erdal 2016).

Thus, Anjum states that some parts of Pakistan may be free of violence, but the entire country - and particularly the poor - are affected by the country's protracted electricity crisis. In his view, most Pakistani asylum-seekers in Germany are poor. Anjum 
believes that his hometown is free from violence, but points out that $\mathrm{Karachi}^{1}$, where a majority of the people from poor rural towns and villages have historically found employment, remains politically unstable. In this regard, political and economical instability intersect since it becomes difficult for people from smaller towns relatively free of violence, to move to larger cities where political conflicts are more common.

Migrants who in normative situations would have been characterised as voluntary migrants need now be understood in differing ways since political violence (in core cities) and economic hardships and conflicts (in villages) as was pointed out by Anjum depicts that can no longer relocate to Karachi. Their decisions to not to internally migrate because of the prevalence of violence in Karachi (Gayer 2014) demonstrate their agency as well as their insights of the situation which they refuse to negotiate with. However, more significantly, the category 'refugee' cannot be privileged over 'economic migrants' because it is the poor who can no longer migrate to regions, affected by political violence and thus have to select safer destinations within Europe. The economically secure people in smaller towns would not necessary need to leave for a city to improve their life chances. In this context, the people who have not experienced direct violence cannot be understood solely as economic migrants because by making the decision to travel to Europe they protect themselves against potential political violence in bigger cities.

\footnotetext{
${ }^{1}$ Karachi has been affected by much internal political violence, particularly on account of the activities of a political party Muttahida Quami Movement (MQM). The MQM's party leader Altaf Hussain, whilst living in London, has had a stronghold in Karachi for several years and has been the cause of much divisive politics and violence in the city.
} 


\section{Concluding Comments}

Much scholarship has noted the intersections between 'forced migration' and 'voluntary migration' but there has been less discussion of how migrants from a specific nation-state themselves understand and experience this nexus. Several studies have been critical of policies and discourses privileging one category over another. Crawley and Skleparis (2017) contend that the lives of those on the move are complex and are not simply a sum of the categories that are constructed around them since people shift between and across categories both in their countries of origin and as they travel through space and time. This study aimed to further build on these theoretical viewpoints and problematize categorization through a detailed examination of complex experiences of Pakistani migrants. In doing so, the study captures the migrants' own understanding for deserving of legal status, their agency in deciding not to contend with difficult situation in their countries of origin, and their understanding of ways in political violence and economic deprivation interlocked. In doing so, this essay illustrated that Pakistani migrants saw themselves caught in the web of corruption, the country's protracted electricity crisis, and an ever-increasing political violence in specified areas and regions, even though in more recent times there have been some steps put forward to improve the economic circumstances. The participants believed that the state's economic deprivation; corruption and political violence affected the poor on individual levels. In this regard, the essay highlighted of how migrants from a specific state understood their specific situation in multi-dimensional ways such that it was not possible to categorize them as either 'refugees' or 'economic migrants'.

These migrants' experiences of their situation in their homeland showed that political conflicts, economic inequalities and corruption needed to be understood in 
their full complexity. Thus, this essay has discussed how multiple factors came to intersect, since many people who experienced direct political violence also lived in impoverished regions where the violence had been of frequent occurrence. The people had little recourse and resources against corruption, received less media attention than their wealthier counterparts, were unable to migrate to urban cities where the violence was also prevalent, and were generally more exposed to violence in public spaces.

The participants understood that they were forced to leave because of a complex set of economic and political factors. In this regard the definition of what constitutes a refugee does not always match the experiences of people who might be forced to leave their nation-states. The migrants with whom I spoke with defined themselves in accordance with the UNHCR 1951 refugee definition only to a certain extent since they included descriptions of socioeconomic rights together with experiences of fear of political persecution. In this sense, they understood themselves as forced migrants, deserving of refugee status, but they provided a complex set of reasons rather than simply narrating experiences of political persecution.

Such an analysis raises questions about the legitimacy of privileging the category 'refugee' over 'economic migrants' within policy, legal discourse and the media. This nexus of political and economic violence needs recognition by the UNHCR 1951 convention as well as in related policies, legislation and media discourse. Very often, migrants are compelled to present themselves solely as victims of political violence in order to gain formal status in host states when in actuality they are affected by both. Only too often, people from poorer nations such as Pakistan are often understood simply as 'economic migrants' in ways that this category is oversimplified and they remain unsuccessful in receiving status. A policy, which 
recognises economic deprivation, as part of political uncertainties would better reflect the lived experiences of many migrants.

\section{References}

Abdin, Z. U., \& Erdal, M. B. (2016). Remittance-sending among Pakistani taxidrivers in Barcelona and Oslo: implications of migration-trajectories and the protracted electricity crisis in Pakistan. Migration and Development, 5(3), 378-393.

Aman, M. M., Jasmon, G. B., Ghufran, A., Bakar, A. H. A., \& Mokhlis, H. (2013). Investigating possible wind energy potential to meet the power shortage in Karachi. Renewable and Sustainable Energy Reviews, 18, 528-542.

Bartram, D. (2015). Forced migration and "rejected alternatives": A conceptual refinement. Journal of Immigrant \& Refugee Studies. 13(4), 439-456.

Berg, S. (1988) Snowball sampling, in Kotz, S. and Johnson, N. L. (Eds.) Encyclopaedia of Statistical Sciences Vol. 8.

Boehler, P. and K.K. Rebecca Lai (2016, March 29) 'How often terror attack strike Pakistan'. New York Times. Retrieved from http://www.nytimes.com/interactive/2016/03/28/world/asia/pakistan-terrorist-attackshistory.html

Bologani, M. and M. B. Erdal (2017) Return Imaginaries and Political Climate: Comparing Thinking about Return Mobilities among Pakistani Origin Migrants and Descendants in Norway and the UK. Journal of International Migration and Integration. 18 (1), 353-367.

Castells, M. (2000) The Rise of the Network Society: $2^{\text {nd }}$ edition. Malden, MA: Blackwell Publishing.

Crawley, H. \& D. Skleparis (2017) Refugees, migrants, neither, both: categorical fetishism and the politics of bounding in Europe's 'migration crisis', Journal of Ethnic and Migration Studies, DOI: 10.1080/1369183X.2017.1348224

Doig and Riley (1998) Corruption and Anti-Corruption Strategies: Issues and Case Studies from Developing Countries.

Ellahia, N. (2011). Testing the relationship between electricity supply, development of industrial sector and economic growth: An empirical analysis using time series data for Pakistan. International Journal of Management Science and Engineering Management. 6, 272-277. 
Erdal, M. B. (2016). Juxtaposing Pakistani diaspora policy with migrants' transnational citizenship practices. Geoforum. 76, 1-10

Gayer, L. (2014) Karachi: Ordered Disorder and the Struggle for the City. India: Harper Collins Publishers.

Gazdar, H. July-September (2003). 'A Review of Migration Issues in Pakistan.' UDBASTU: A Newsletter on Refugees and Migratory Movements, Issue 25. Dhaka:RMMRU. Retrieved from: http://www.eldis.org/vfile/upload/1/document/0903/Dhaka_CP_4.pdf

Ghoshal, A. and T.M. Crowley (1983) 'Political versus Economic Refugees', Review of Social Economy. 41(2): 124-136.

Gonzalez, M. (2001) 'UK Refugees from globalism' Race and Class. 42(3): 87-100.

Hasan, A. (2010) 'Migration, small towns and social transformation in Pakistan', International Institute for Environment and Development. 22(1): 33-50.

Jamil, F., \& Ahmad, E. (2010). The relationship between electricity consumption, electricity prices and GDP in Pakistan. Energy Policy, 38, 6016-6025.

Jamil, F. (2013). On the electricity shortage, price and electricity theft nexus. Energy Policy, 54, 267-272.

Kalra, V. S. (Ed.). (2009). Pakistani Diasporas: Culture, conflict, and change. Pakistan: Oxford University Press.

Kalra, V. (2000). From Textile Mills to Taxi Ranks: Experiences of Migration, Labour and Social Change. Aldershot: Ashgate.

Khan, M. (2012, December 12) 'Karachi Cantt Bomb Blast kills 7.' The Nation. Retrieved from http://nation.com.pk/editors-picks/30-Dec-2012/karachi-cantt-bombblast-kills-7.

Klinck, J.A. (2009) 'Recognising Socio-Economic Refugees in South Africa: a principled and rights-based approach to section 3(b) of the refugees act, International Journal of Refugees Law. 21 (4): 653.

Koser, K. and Martin, S. (2011) (eds) The migration-displacement nexus: Patterns, processes, and policies. Oxford: Berghahn Books

Kyriakedes, C. (2016) 'Words don't come easy: Al-Jazeera's migrant-refugee distinction and the European culture of (mis)trust' Current Sociology. DOI:

10.1177/0011392116658089 1-20 
Lindley, A. (2010). Leaving Mogadishu: Towards a sociology of conflict-related mobility. Journal of Refugee Studies. 23(1): 2-22

Malone, B. (2015, 20 August) 'Why Al Jazeera will not say Mediterranean 'migrants' Al-Jazeera

Retrieved from http://www.aljazeera.com/blogs/editors-blog/2015/08/al-jazeeramediterranean-migrants-150820082226309.html

Nyers, P. (2006) Rethinking Refugees: Beyond States of Emergency. New York, London: Routledge.

Ottonelli, V., and Torresi, T. (2013). When is migration voluntary? International Migration Review. 47(4), 783-813.

Richmond, A. H. (1994). Global apartheid: Refugees, racism, and the new world order. Oxford, UK: Oxford University Press.

Shabbaz, M., \& Lean, H. H. (2012). The dynamics of electricity consumption and economic growth: A revisit study of their causality in Pakistan. Energy, 39, 146-153.

Rytter, M. (2013) Family Upheaval: Generation, Mobility, and Relatedness among Pakistani Migrants in Denmark. New York: Oxford, Berghahn Books.

Strange, M., V.Squire and A. Lundberg (2017) Irregular migration struggles and active subjects of trans-border politics: New research strategies for interrogating the agency of the marginalised. Politics, 37 (3) 243-253.

Squire, V. (2017) Unauthorised migration beyond structure/agency? Acts, interventions, effects. Politics, 37(3) 254-272

Van Hear, N. (2006a) "“I went as far as my money would take me': conflict, forced migration and class", in F Crepeau et al eds. Forced migration and global processes: a view from forced migration studies, Lanham MA: Lexington/Rowman and Littlefield, 2006, 125-158.

Van Hear (2009) 'Managing Mobility for Human Development: The Growing Salience of Mixed Migration’. Human Development Research Paper.

Vihe, M. F. (2007) Migration movements between Pakistan and South Western Europe: Pakistani migratory networks in Catalonia. Departament de Geografia. Barcelona, Universitat Autonoma de Barcelona.

Werbner, P. (2002) Imagined Diasporas among Manchester Muslims. Oxford: James Curry Press. 
Haq,S. and D. Walsh 'Inside the Taliban's besieged Swat fortress as battle rages' Guardian. 10 May 2009. Accessed online 10 April 2017.

Wade, R. (1985) 'The Market For Public Office: Why India is Not Better at Development.' World Development 13: (4).

Yousef, K. (2013) 'The Vicious Circle of Irregular Migration from Pakistan to Greece and back to Pakistan.' Background Report: Migratory System 3 (Pakistan). Hellenic Foundation for European and Foreign Policy (ELIAMEP). Athens: Greece.

Zetter, R. (2007). More labels, fewer refugees: Remaking the refugee label in an era of globalization. Journal of Refugee Studies, 20(2), 172-192. 